\title{
Translation of Idioms: A Hard Task for the Translator
}

\author{
Amineh Adelnia \\ University of Isfahan, Isfahan, Iran \\ Email: Adelnia_am@yahoo.com \\ Hossein Vahid Dastjerdi \\ English Department, University of Isfahan, Isfahan, Iran \\ Email: H_vahid@yahoo.com
}

\begin{abstract}
Idioms can be considered as a part of everyday language. They are the essence of any language and the most problematic part to handle with. Not all idioms have direct equivalents in another language, because they are linguistic expressions which are typical for a language and specific to a single culture. It is impossible to define any unique approach in the translating process since so many idioms are culturally specific and thus the pragmatic meaning must be much more prized than the literal meaning. If they are to be translated literally or word for word, they lead to extreme confusion. The present study investigates some important idioms in the book What You Asked For, and provides the readers with the procedures and strategies used to translate them. The procedures are proposed by Baker (1992). This paper presents the definition of idioms to see what they are. Then, it classifies the idioms into different categories and in the end, gives some techniques and procedures to translate them.
\end{abstract}

Index Terms - translation, idioms, classification of idioms, equivalents, culture specific, translation strategies

\section{INTRODUCTION}

Translation is used to transfer meaning from one language to another. A written or spoken SL text will be exchanged by its equivalent written or spoken TL text. In most cases, however, we as translators can not find the proper equivalent of some of the SL items. According to Culler (1976), languages contain concepts which differ radically from those of another, since each language organizes the world differently. When we compare languages we find that different cultures have identified similar social observations and according to their knowledge and experience coin their own phrases. So we can conclude that the disparity among languages are problematic for translators and the more different the concepts of languages are, the more difficult it is to transfer messages from one language to the other. Among the troublesome factors involved in the process of translation is the transference of form, meaning, style, proverbs, idioms, etc. Before going deep into the discussion, there is a need to define idioms to distinguish them from non-idioms.

\section{DEFINITION OF IDIOMS}

Idioms are linguistic expressions or lexical items representing objects, concepts or phenomena of material life particular to a given culture. They are necessary to any language in order to keep the local and cultural color of that language. In a definition given by Larson idiom is "a string of words whose meaning is different from the meaning conveyed by the individual words" (Larson, 1984, p.20). In another place he states that idiom "carries certain emotive connotations not expressed in the other lexical items" (Larson, 1984, p.142). In Longman dictionary of English idioms (Longman Group Ltd: 1979) idioms are referred to as "a fixed group of words with a special different meaning from the meaning of the separate words". So the first thing to mention here is that idioms can not be translated literally because their meaning won't be predicted from the usual meaning of their constituents. For example the idiom it was a pretty kettle of fish refers to a messy situation and in Farsi is translated as آش شله قلمكارى بود كه نكو. Here there is nothing to do with the kettle, a utensil in the kitchen, or the fish, an animal living in water. We can see that if this idiom will be translated word by word as بك كترى قثنغ ماهيى بود it will make no sense to the readers.

In her book, In Other Words, Mona Baker (1992) states that idioms are frozen patterns of language which allow little or no variation in form and often carry meanings which can not be deduced from their individual components. So by stating this definition she considers five conditions for idioms which come as follow:

1) The order of the words in an idiom cannot be changed. The way the words are put together is fixed and they can not change their place. E.g. "go to rack and ruin" not "go to ruin and rack".

2) The words in an idiom can not be omitted. We as the users of the language are not permitted to delete some of the words of a particular element. E.g. "shed crocodile tears" not "shed tears".

3) There are no extra words that might be added to an idiom. E.g. "have a narrow escape" not "have a narrow quick 
escape".

4) No words in an idiom can be replaced by another word. E.g. "out of sight, out of mind" not "out of sight, out of heart".

5) The grammatical structures of an idiom can not also be changed. We have the idiom of "ring the bell" but we don't have "the bell was ringed".

\section{CLASSIFICATION OF IDIOMS}

Translating idioms is a very difficult task for a translator especially if he is not aware of the cultural differences of the source and target languages. The main problem for him is recognizing idioms and distinguishing idiomatic from non-idiomatic expressions. In order to help to understand idioms better, there is a classification of them. Idioms can be grouped into five categories of colloquialisms, proverbs, slang, allusions and phrasal verbs. Below is a brief definition of each with some examples.

\section{A. Colloquialism}

Colloquialism is an expression not used in formal speech or writing. Colloquialism or colloquial language is considered to be characteristic of or only appropriate for casual, ordinary, familiar, or informal conversation rather than formal speech or writing. They are used in daily conversations. For example in the case a person laughs a lot we طرف از خنده روده بر ش (he died of laughter). It is an informal way of saying زياد خنديد (laughed a lot). Another example of colloquialism can be the expression of از دهنم ير بريد which is used the time that we say something by accident and not deliberately.

Colloquialism is often used primarily within a limited geographical area. Example of this geographical type of colloquialism is the use of the word هم ريش by the people living in Isfahan and the word هم داماد by the people living in Yazd (a city near Isfahan). They refer to one item differently. Both of them refer to the husband of one's wife's sister but not in a similar way.

\section{B. Proverbs}

Proverb is a simple way of speaking. It is used the time when we want to make our speech more concrete and more understandable. It is popularly used and repeated and expresses facts and truth based on common sense. Wolfgang Mieder is an American scholar working on proverb. He defines proverb as follows:

A proverb is a short, generally known sentence of the folk which contains wisdom, truth, morals, and traditional views in a metaphorical, fixed and memorizable form and which is handed down from generation to generation (Mieder 1985, p.119; also in 1993, p.24).

The reason to use proverbs can be to choose a way of saying a fact gently and smoothly and to make it more reliable and valid. Other times, they are used to carry more weight in a discussion. Another reason can be to give more taste and beauty to our speech. Good speakers try to make use of proverbs to attract their audience.

Examples of proverbs in Farsi can be خواهى نشوى رسوا همرنگ جماعت شو (in Rome do as the Romans do) or the expression نابرده رنج كنج ميسر نمى شود (no pain, no gain) which refers to the situation of suffering in order to gain the thing we have intended to achieve.

\section{Slang}

Slang is the use of highly informal words and expressions that are not considered as the standard use of language. It is often used as a way to say words that are not appropriate or somehow taboo. Dumas and Lighter (1978) argue that slang lowers the dignity of formal or serious speech or writing and replace a well-known conventional synonym. Slang is used to add humor and fun to one's speech. An example of slang can be مرده ع متحرك which is the time when somebody is looking extremely ill, or the term بز كر which points to something very different from others in the same group. The term خفن in Farsi is another slang used mostly by teenagers and refers to something very cool.

\section{Allusions}

Allusion is a figure of speech that makes a reference to a place, event, literary work, myth, or work of art, either directly or by implication. Abrams (1971) defined allusion as "a brief reference, explicit or indirect, to a person, place or event, or to another literary work or passage".

To give an example of allusion we can refer to the expression of ياسين به كوش خر خواندن which implies doing something of no worth or performing an action of no importance. Another example can be برن خرن which is an allusion to the city of Kerman and is equivalent to the expression of bring coal to the Newcastle.

\section{E. Phrasal Verbs}

Phrasal verb is the combination of a verb and a preposition, a verb and an adverb, or a verb with both an adverb and a preposition. A phrasal verb often has a meaning which is different from the original verb.

They are usually used informally in everyday speech as opposed to the more formal verbs. For example the informal use of to go on instead of the word to continue or the use of to hand in rather than to deliver. 
When a translator recognizes an idiom and distinguishes it from non-idiomatic expressions, the next step is to select the suitable strategy to translate it. Of course in the beginning of his work, he will face some difficulties and problems. He should investigate which strategy is more appropriate in dealing with the translation of the source idiom into the target language.

Most of the time, a source language idiom has no equivalent in the target language. This can be a very important factor a translator should notice. Different languages express different concepts and realities in a different way which is particular to that language. Therefore, sometimes a same concept or idea is referred to distinctly in two different languages. Of course it does not mean that because the idiom has not its equivalent in the TL it should not be translated. The translator tries to translate it in a way that the sense won't be lost. In translating "to carry coals to Newcastle" the translator has no problem during his process of translation because it has an equivalent in Persian as “بره به كرمان " بردن. The meaning and the sense is the same in both Persian and English languages. It means to offer someone the thing which he has already plenty of.

\section{TRANSLATION STRATEGIES FOR TRANSLATING IDIOMS}

The way an idiom is to be translated depends on the context in which it is used. We have different and various translation strategies but the translator should see the use of which kind of these strategies can help the target language readers to better comprehend the meaning of the idioms. When translating a source idiom the translator should be conscious of the sense. He may change some aspects of the idiom to preserve the sense and to transfer it to the TL readers. In the case that the original idiom does not have its equivalent in another language, the translator should not delete that idiom from his text but he should clarify more on it to let the readers understand its meaning better. Fernando and Flavell express that there is "strong unconscious urge in most translators to search hard for an idiom in the receptor language, however inappropriate it may be" (1981, p.82).

The strategies which are used in this article are those proposed by Mona Baker (1992). They are going to be illustrated more by using some examples of idiomatic expressions in both English and Persian as the source and target languages.

\section{A. Using an Idiom of Similar Meaning and Form}

By using this strategy, the translator tries to find an idiom in the target language which is equivalent to the source language both in terms of meaning as well as lexical items. This strategy is hardly achieved because languages differ radically in the way they identify a single concept. However, it is regarded as the ideal strategy for translating idioms. In the example of.

SL:

Things are not always what they seem

$$
\text { هيز ها هميثـه آنظور كه به نظر مي رسند نيسنن }
$$

I'm all ears

سرابا كوشم

Has the cat got your tongue?

كرببه زبونتو خورده

We keep both the meaning and the form of the source language idiom and have an exact equivalent for it. Here the lexical items are remained the same and the sense is not lost at all.

\section{B. Using an Idiom of Similar Meaning but Dissimilar Form}

In this case the meaning of the target idiom is the same as that of the original idiom but the lexical items are different. Here you are provided with some examples.

SL:

Out of sight, out of mind

از دل برود هر آنكه از ديده برفت

While the cats away, the mice will play

آب كه سربالا مبره قورباغه /بوعطا مي خونه

A bird in the hand is worth two in the bush

سبلي نقد به از حلواي نسيب

In the examples above, in order to represent the same meaning, we make use of different lexical items.

\section{Translation by Paraphrase}

This strategy is most commonly used in the process of translating idioms in the cases that the translator cannot find any equivalents for the source idiom. Earlier in the article, it was pointed out that when no equivalents exist, it is not a wise act to omit the whole idiom but to present more clarifications on it. Because of the lexical or stylistic differences between the two languages, we will not always have correspondence. We should elaborate more on the source idiom to transfer its meaning to the target language. It is noted here that the given meaning would not be an exact equivalent or semantic equivalent of the source idiom. 
SL:

He is a supergrass

طرف آدم خبربر و فضوليه

You mark my words

از من كفتن بود حالا هر كاري دوست داري بكن

First things first

از نان شب واجب تره

Of course by using this strategy we will face the danger of losing the intended effect that the source language wanted to have on its audience. It will also lose the cultural significance. The target readers would not have the chance of getting more familiar with the culture of the source language. Mona Baker defines paraphrasing as "translating a source language idiom by giving its meaning in the target language. By using this strategy the impact of the idiom and its cultural significance will be lost (Baker, 1992, p.74).

\section{Translation by Omission}

The time that there is no close match between the languages' items or the time that the translator cannot find any equivalents, this strategy is used to completely omit the idiom from the target text. When the idiom is very difficult even for the translator, he tries to eliminate the whole or part of the idiom like the examples below:

SL:

I couldn't make head or tail of his talk

از حرفاش جيزي سر در نياوردم

She has nerves of steel

اعصابش خوبه

She offered a left-handed compliment.

تعارف كرد

It is observed here that the translator has omitted some parts of the idioms and has changed an idiomatic expression into a non-idiomatic sentence. So the significance of the words in the source idiom is not transferred by the way the translator has translated them.

Another strategy which is proposed by Baker (1992) is giving a literal translation of the target idiom. Of course the literal version of the idiom should be acceptable by the target readers and it should be lexically modified. In the case of not finding a proper equivalent, giving a literal translation is not always an easy task to do. Because the more literal a text is translated, the more confusion it brings to the readers. According to Newmark literal translation is translating an idiom by giving a word-for-word translation of the source language idiom, which most of the time results in unnatural or wrong rendering of idioms (1988, p.69).

Translating "A rotten apple" literally as سيب كنديده is somehow obscure and won't transfer the sense at all. In order to avoid confusion, the correct way is to translate it as وصله

When translating an idiom into the target language the translator should be cautious of the original effects the writer intends to present. He must be very careful not to lose the sense for his target readers. In the case of giving a literal translation, the translator should choose those equivalents which carry the same cultural effects as that of the original.

\section{CONCLusion}

Translating idioms are arguably the most complex and problematic task for translators. Gottlieb suggests that "an idiom is difficult to decode correctly for someone who only knows the normal meanings of its constituent elements" (1997, p.260). In another statement proposed by Beekman and Callow, idioms are defined as "the combination of at least two words which cannot be understood literally and which function as a unit semantically" (1997, p.49).

There are some strategies which can be used for the translation of idioms. The translator should choose a proper strategy according to the purpose of the translation but at the same time bears in mind that nothing should be eliminated. Every concept in one particular language has its own correspondent in another language. So omitting a word or an idiom from a text is not a wise action to take.

In order to better translate an idiom, the translator should identify it from those expressions which are not idioms. Then investigates the classification to which that particular idiom belongs and selects the suitable strategy for his translation. During this process, the translator should be careful of the naturalness and readability of his text. He would better try his best to find equivalences to transfer both the form and the meaning and be thoughtful of not deleting the whole or eliminating the part of the idiom there is no correspondence for. Larson (1984) states that "the translator also needs to develop sensitivity to the use of idioms in the receptor language and uses them naturally to make the translation lively and keep the style of the source language. There will often be words in the source language which are not idioms but are best translated with an idiom (Larson, 1984, p.116).

\section{REFERENCES}


[1] Abrams, M. H. (1993). A Glossary of Literary Terms. 6th edition. Fort Worth: Harcourt Brace College Pub.

[2] Baker, M. (1992). In Other Words: A Course Book on Translation. London and New York: Routledge.

[3] Beekman, J. \& Callow, J. (1974).Translating the Word of God. Grand Rapids, MI: Zondervan.

[4] Culler, J.(1976). Saussure (American Title: Ferdinand de Saussure). London: Fontana; Brighton: Harvester, 1976. New York: Penguin, 1977. Second revised edition, Ithaca: Cornell University Press, 1986; London: Fontana, 1987.

[5] Dumas, Bethany K. and Lighter, Jonathan. (1978). "Is Slang a Word for Linguists?" American Speech 53 (5): 14-15.

[6] Fernando, C. and Flavell, R. (1981). On Idiom: Critical View and Perspectives (Exeter Linguistic Studies), University of Exeter.

[7] Gottlieb, H. (1997). You Got the Picture? On the Polysemiotics of Subtitling Wordplay. In: D. Delabastita. Ed. Essays on Punning and Translation. Manchester: St. Jerome in Cooperation With Presses Universities de. Namur, Belgium.

[8] Larson, M.L. (1984). Meaning Based Translation: A Guide to Cross Language Equivalence. London and New York: University Press of America.

[9] Longman Dictionary of Idioms. (1998). UK: Longman.

[10] Mieder, Wolfgang. (1982). Proverbs in Nazi Germany: The Promulgation of Anti-Semitism and Stereotypes Through Folklore. The Journal of American Folklore 95, No. 378, pp. 435-464.

[11] Mieder, Wolfgang. (1982; 1990; 1993). International Proverb Scholarship: An Annotated Bibliography, with supplements. New York: Garland Publishing.

[12] Mieder, Wolfgang. (1994). Wise Words: Essays on the Proverb. New York: Garland.

[13] Mieder, Wolfgang and Alan Dundes. (1994). The wisdom of many: essays on the proverb. (Originally published in 1981 by Garland.) Madison: University of Wisconsin Press.

[14] Mieder, Wolfgang. (2001). International Proverb Scholarship: An Annotated Bibliography. Supplement III (1990-2000). Bern, New York: Peter Lang.

[15] Mieder, Wolfgang and Anna Tothne Litovkina. (2002). Twisted Wisdom: Modern Anti-Proverbs. New York: DeProverbio.

[16] Mieder, Wolfgang. (2004). Proverbs: A Handbook. (Greenwood Folklore Handbooks). New York: Greenwood Press.

[17] Molla, I. (2009). What you asked for. Tehran: Moallef.

[18] Newmark, p. (1988). A Textbook of Translation. New York and London: Practice - hall.

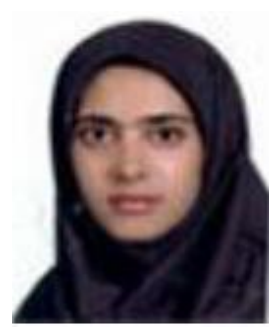

Amineh Adelnia (b. 1987, Isfahan, Iran) is currently a Ph. D. candidate at the University of Isfahan, Isfahan, Iran. She received her M.A. in English Translation at the University of Isfahan, Isfahan, Iran (2011) following the completion of her B.A. in English Translation from Kashan University, Kashan, Iran (2008). Her main research areas of interest are: Translation Studies, Films' Subtitling and also Second Language Acquisition. She has been working as an EFL instructor since 2004.

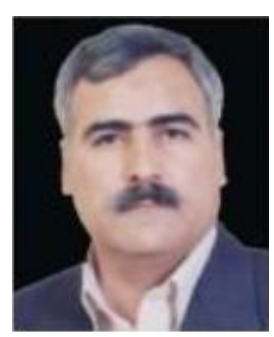

Hossein Vahid Dastjerdi (b. 1955, Isfahan, Iran) teaches in the English Language Department at the University of Isfahan, Iran. He is associate professor of applied linguistics and has taught courses of variegated character, including translation courses, for years. He has been a fellow of the English Centers at the universities of Isfahan and Shiraz where he has investigated into issues related to materials preparation for GE. and ESP. courses. He is the author of a number of books in this respect. He has also published a good number of articles on discourse, testing and translation in local and international journals.

Dr. Vahid's current research interests include testing, materials development, translation, the metaphoricity of language, discourse analysis, pragmatics and critical discourse analysis. He is presently involved in a number of projects concerning translation studies as well as figurative language use. 